\title{
Entrepreneurial Level Factors of Early Internationalization: a Cross Country Comparison
}

\author{
Jurgita Sekliuckiene', Miroslaw Jarosinski², Miklos Kozma ${ }^{3}$
}

${ }^{1}$ Kaunas University of Technology

Gedimino str. 50 -415, LT-44239, Kaunas, Lithuania

E-mail.jurgita.sekliuckiene@ktu.lt

${ }^{2}$ Warsaw School of Economics

Al. Niepodleglosci 164, Warsaw, Poland

E-mail.mjaros@sgh.waw.pl

${ }^{3}$ Corvinus University of Budapest

H-1093 Budapest, Fovam ter 8, Hungary

E-mail.miklos.kozma@uni-corvinus.hu

cross $^{\text {ref }}$ http://dx.doi.org/10.5755/j01.ee.30.2.21185

International new ventures proved to contribute positively to national economies they derive from. This article analyses the entrepreneurial level factors of success at the startup stage of international new ventures (INVs) in the context of three Central and Eastern European (CEE) countries in transition: Hungary, Lithuania and Poland. Based on multiple case study approach, the study provides important insights into the international entrepreneurship theory by examining the still underexplored transition in CEE countries' context. An in-depth qualitative analysis has been performed based on 9 case studies, 3 INVs from each country. Lots of similarities emerge between INVs in three CEE countries, however their cultural and historical backgrounds are different enough to justify scholarly interest in potential idiosyncratic features. Findings suggest that there is significant diversity in the entrepreneurial level factors behind the early success of local INVs in international markets across these countries, especially in terms of direct foreign market experience, entrepreneurial orientation and existing network membership. Nevertheless, the findings reveal that in the sample focused on ITC businesses, solid industry experience of the founders proved to be key in the success of INVs' internationalisation.

Keywords: International New Ventures; Early Internationalization; Transition Economy; CEE; Hungary; Lithuania; Poland.

\section{Introduction}

International entrepreneurship is becoming an important and increasingly recognized field in the academic literature (McDougall \& Oviatt, 2000; Oviatt \& McDougall, 2005; Kuivalainen et al., 2010; Rialp et al., 2015; Servantie et al., 2016; Martin \& Javalgi, 2018). This phenomenon mostly occurs in small- medium sized businesses that expand internationally very quickly. Such firms act as a countervailing power in the markets, which is forcing the larger firms to act more competitively, maintain a balance between quantity and price and alleviate other problems associated with property rights of larger companies (Ovaska \& Sobel, 2005). The strength of the research field is highlighted by scholarly efforts applying specific tests on general international entrepreneurship theories on small and medium sized firms (Naldi et al. 2015; cf. Etemad, 2017). In emerging and transitional countries, the relevance of such firms is even more relevant, as they are more prone to the risk perceptions that primarily drive their willingness and ability to internationalise (Ngo et al., 2016). In addition, small and medium sized enterprises not only contribute to the wealth and job generation possibilities, but provide additional potential welfare gains for the economy and society too.

Small and medium sized enterprises are a powerful engine for countries undergoing radical changes (e.g. Baltic States after the collapse of the Soviet Union, Central Eastern European Countries) because they could foster innovation, experimentation and adaptation in the business environment (European Bank for Reconstruction and Development, 1999).

The emergence of early internationalized small and medium sized firms called most often international new ventures (INVs) or born globals (BGs) inspired a wave of research that concentrated on developed countries (Mathews \& Zander, 2007; Kuivalainen et al., 2010; Gabrielsson \& Gabrielsson, 2013), including metaanalyses of the research field (Santos \& Barandas, 2015; Choquette et al., 2017; Garcia-Lillo et al., 2017; Dzikowski, 2018), but much less research focused on transition economies like the Central and Eastern European (CEE) countries (Vissak, 2006; Jarosinski, 2012; Nowinski \& Rialp, 2013; Ferencikova, 2014; Ciszewska-Mlinaric et al., 2016; Sekliuckiene, 2017; Jarosinski \& Mierzejewska, 2017). 
Born globals/international new ventures contribute positively to national economies they derive from, through better productivity, better profitability, higher innovation levels and bigger employment effect than other young enterprises (Eurofound, 2012).

Although the attention to contextual aspects of internationalization of INVs is growing, little is known about different drivers and success factors of international new ventures from transition economies in CEE. The first studies touching on the determinants of the success of Polish born globals/international new ventures (Jarosinski, 2013; Jarosinski \& Mierzejewska, 2017; Danik \& Kowalik 2015), drivers of early internationalization of INVs in Lithuania (Sekliuckiene, 2017) and Hungary (Czako \& Konczol, 2014) have already appeared but they do not cover the topic in a sufficient way yet. Moreover, most of these studies uncovered the critical drivers using samples exclusively focused on single countries. Comparative studies have been much fewer although the findings from extant literature highlight the relevance of culture and history shared across these countries. Thus in line with recent trends in international business research (Poulis et al., 2013), we adopt a contextual approach. We study the entrepreneurial related factors of INVs in transition countries: Hungary, Lithuania and Poland. We believe that our findings will reveal specifics related to CEE economies in transition context as "special treatment of international new ventures from CEE transition economies is justified" (Nowinski \& Rialp, 2013, p. 191).

We seek to compare and contrast our findings from three different countries in the region regarding the success factors related to INVs, more particularly related to the founder - entrepreneurial factors. Two of the most liberal countries under the Soviet influence, Poland and Hungary, as well as a former member of the Soviet bloc, Lithuania were selected in our sample. There is an important connecting strand for all post-Soviet countries. The development of legalized entrepreneurship, in the form of private business ownership, was the major change. Thus, all the three countries share similar though not uniform historical backgrounds, but the sizes of their domestic markets are strikingly different. Poland is the largest market. Hungary shares many similarities culturally and historically with Poland (more than with others countries in CEE), but its size is app. $25 \%$ of Poland. This in itself makes the comparison of INV entrepreneur-related success factors interesting for scholarly analysis. Regarding Lithuania, it was not just influenced by the Soviet Union, but was actually part of it, and it is even smaller (app. $25 \%$ of Hungary), so one would expect quicker and more radical reforms there than in the two larger countries. Moreover, all three countries are at different intensity level of entrepreneurship.

Thus, the aim of this paper is to analyse the founderentrepreneur factors of early internationalization of INVs and present the results of the research on factors of INVs deriving from CEE economies in transition: Hungary, Lithuania and Poland (countries are mentioned by alphabetical order throughout the paper). At the same time we identify similarities and differences in the three countries under investigation. Our research questions are: What entrepreneur related factors drive early internationalization of INVs in the region? How much are, if at all, the entrepreneurial approaches and competences of their founders critical in their internationalisation? In order to address this issues we performed an in-depth qualitative analysis on 9 case studies (3 from Hungary, 3 from Lithuania and 3 from Poland).

In the first part of the paper theoretical aspects of the entrepreneurial related drivers are identified. Then, the research methodology is discussed. Next, the cases description and the results of comparative cross country research are presented. Finally research limitations and proposals for future research on the topic are debated.

\section{Literature Review}

Explaining drivers of early internationalization researchers (Andersson et al., 2015; Felicio et al., 2014; Amoros et al., 2014; Michailova, 2015; Sekliuckiene, 2017; Jarosinski \& Mierzejewska, 2017) usually describe different level factors, such as: entrepreneurial/managerial level (e.g., global mindset, experience, entrepreneurial orientation, social capital, etc.); firm-related level (e.g., resources, knowledges, capabilities, business model, strategy, etc.); and contextual determinants (e.g., industry factors, competition/ environmental dynamism, funding possibilities: private equity and venture capital, different types of environments, etc.).

There are separate streams of literature that emphasize the role of founder/entrepreneur at the start up stage of international new ventures. Many variables, related to the background of the founder/entrepreneur are defined as very important during the early internationalization stage of INVs. Researchers focuse on the role of the entrepreneur's human capital, especially his or her age (Cressy, 1996; Stucki, 2016), finding that age and support networks positively affect business performance (Masuo et al., 2001), and emphasized the age effect on entrepreneurial behavior (Sekliuckiene et al., 2017). At the same time some other authors (Gimmon \& Levie, 2010) do not see age as indication of human capital.

The sources of so understood success of INVs are seen in particular in the earlier experience of the founder (Danik \& Kowalik, 2015; Jarosinski \& Mierzejewska, 2017) and characteristics of the founder (Rasmussen \& Madsen, 2002; Rialp - Criado et al. 2002; Anderson \& Evangelista, 2006; Jarosinski, 2012). Scholars emphasized the impact of prior entrepreneurial exposure on perceptions of new venture feasibility and desirability (Krueger, 1993); possession of prior experience, business interests and number of years' experience in the current industry (Roper, 1999). Some scholars believe that the deficiencies in market knowledge normally gathered during the firms' development are overcome by the knowledge and experience gathered by the founder in the period before establishing the firm. Moen \& Servais (2002) give market knowledge, experience resulting from previous engagements and education as examples of skills possessed by entrepreneurs before the establishment of a firm. Moreover, Reid (1981) notice the importance of factors such as earlier education, background or the fact of being born abroad at the moment of consideration of entry into foreign markets. 
Most studies on entrepreneurial level variables have focused on the development of a global mindset, such as international orientation, experience or education abroad (Harveston et al. 2000); young entrepreneurial behavior, e.g., risk tolerance and work values related motivation (Damon \& Lerner, 2008). Referring to Andersson and Evangelista (2006) research, earlier industry experience and earlier international experience are important, however insufficient in themselves. They also found out that not all the founders of the surveyed firms had an earlier professional experience but had a global mindset and very strong ambitions to develop their own business. They also found out in the research on Danish and Australian born globals that early internationalisation was not necessarily connected with earlier experience of their founders but the founders were characterized by international orientation which is a part of founders' characteristics (Rasmussen et al., 2001). Entrepreneurial attitudes and characteristics of young entrepreneurs such as openness to new experiences, intentional self-regulation skills, aspects of character (e.g., creativity, curiosity, diligence, future mindedness, and reliability) are critical to INVs success (Geldhof et al., 2014).

The characteristics of a founder meaning his/her character, skills, and way of thinking and international orientation play very important role in establishing a firm, creating its global vision and executing it (Kocak \& Abimbola, 2009). Global vision and orientation become crucial factors of success, e.g., global vision since inception of a firm is an advantage of born globals (Falay et al., 2007). The founder of early internationalizing firm is usually characterized as an open-minded person of strong personality, eager to take risks and having a global way of thinking (Jarosinski, 2012). Such features facilitate bold business decisions and international expansion even in the case of a small firm.

Social capital and networking are especially important at the start up stage of internationalization of INVs. Autio et al., (2005) highlighted social capital (personal or professional relationships and networks usage) as an essential factor to the development and success of early internationalized firms. Thus personal networks are important in the organization of a firm and indispensable in its fast development on international markets (Anderson \& Evangelista, 2006; Almeida Moraes et al., 2017). Most of personal networks are usually built before the establishment of a firm. Harris \& Wheeler (2005) proved that almost all strategic relations of entrepreneurs devoted from their earlier social contacts. Personal networks enable firms to establish relationship with foreign firms and also enable to benefit from the partners' experiential knowledge.

\section{Methodology}

Research Method and Interview

The methodological approach of the multiple case study is the most appropriate for understanding a complex and recent phenomenon of entrepreneurial level drivers of early internationalization. This research by its nature is dedicated for better understanding of the phenomenon of early internationalization thus we used explanatory research design, methods of qualitative research in order to identify, analyse and compare research constructs results (Hair et al., 2007; Baxter \& Jack, 2008). We used the case study method as the case analysis is one of the most appropriate approach in order to answer the questions formulated in the research, and to identify the dynamics of a phenomenon's development (Yin, 2009). Case study method is widely used seeking to explore international new ventures (Danik \& Kowalik, 2013; Nowinski \& Rialp 2013; Gabrielsson \& Gabrielsson, 2013; Kowalik et al. 2017).

Primary data were collected by applying the method of a semi-structured interview. Interview scenarios were prepared in English and then translated into Hungarian, Lithuanian and Polish to facilitate data collection. Afterwards the respective interviews were translated into English. This research is a part of the wider research based on the factors driving to early internationalization (Sekliuckiene, 2017; Czako \& Konczol, 2014; Sass, 2012) and success factors of international new ventures (Jarosinski \& Mierzejewska, 2017). Thus relating to the object of this research only entrepreneurial level indicators are described in this paper. The questions related to entrepreneurial level determinants of early internationalization were based on several studies (Knight \& Cavusgil, 1996; Rialp-Criado et al., 2005; Andersson et al., 2015; Gerschewski et al., 2015; Knight \& Liesch, 2016; Lin et al., 2016; Sekliuckiene, 2017). The following variables were included: previous industry experience (Anderson \& Evangelista, 2006), international experience (Anderson \& Evangelista, 2006; Laanti et al, 2007; Kyvik, 2013; Knight \& Liesch, 2016), entrepreneurial orientation (Kuivalainen et al, 2007; Knight \& Liesch, 2016), global mindset (Kyvik, 2013), networks (Knight \& Liesch, 2016; Lin et al., 2016).

\section{Case Selection and Data Collection}

The case selection was the critical phase of this study because firms should represent cases where the theoretical interest would be more evident than in others (Eisenhardt, 1989). We decided to focus on the high tech industry, especially on information technology and communication sector (ITC). ITC sector is receptive to technologies. Moreower, INVs have been found more often in the high-tech industry (Autio et al., 2011). Focus on high-tech companies allow to control for differences related to industry type (Gabrielsson \& Gabrielsson, 2013). Thus we found the ITC small and medium sized firms that met the criteria of INVs. Firms were selected using the following criteria of INVs:

1) a firm must carry out activities abroad immediately or soon after the firm's establishment (Knight \& Cavusgil; 2004);

2) firm's sales revenues in foreign markets exceed $25 \%$ (Knight \& Cavusgil, 2004; Dib et al., 2010; Madsen, 2013);

3) a firm must comply with characteristics of SMEs, the number of employees should not exceed 250, and annual turnover should be no more than 50 million euro.

The final sample consisted of nine high-tech firms that had been established in Hungary, Lithuania and Poland, and were selected for multiple case study analysis (see Table 1): three case studies from each country respectively. According to Eisenhardt (1989), the ideal number of cases is from 4 to 12 as such number of cases is sufficient to notice changes in the INVs from CEE transition economies phenomenon and achieve deeper insights. The interviewed firms internationalized their activities immediately after their establishment or before a maximum of three years. 
The research was conducted between October 2014 and April 2015 in Lithuania; during December 2016 in Hungary and in March 2017 in Poland. Interview time and exact location was planned and coordinated in advance. In each firm one interview was conducted with a key informant that had all necessary information required in the research. The interviewees were founders/members of the founding team, CEOs or managing directors that were with a firm since its establishment or at least from the start of internationalisation.
The interviews were audio-recorded and lasted about 1-1.5 hours. The recorded interviews were transcribed and coded by the authors. The validity of research was ensured by multiple sources of evidence, which provided multiple measures of the same phenomenon (Yin, 2009). Contextual observation and written sources of information, such as annual reports were also used. All the data obtained in the interviews and in the documents were analyzed using the technique of content analysis.

Table 1

\section{Description of the Case Studies}

\begin{tabular}{|c|c|c|c|c|c|c|c|}
\hline Firm & Product/service & $\begin{array}{l}\text { Industry/ } \\
\text { sector }\end{array}$ & $\begin{array}{c}\text { Number } \\
\text { of employees }\end{array}$ & $\begin{array}{c}\text { Year } \\
\text { established }\end{array}$ & $\begin{array}{l}\text { The beginning } \\
\text { of } \\
\text { international } \\
\text { activities }\end{array}$ & $\begin{array}{l}\text { Top Export } \\
\text { Markets }\end{array}$ & $\begin{array}{l}\text { Sales revenue in foreign } \\
\text { markets, approx. }(\%)\end{array}$ \\
\hline \multicolumn{8}{|c|}{ Hungarian INVs } \\
\hline Firm Hl & $\begin{array}{l}\text { Software } \\
\text { development }\end{array}$ & ITC & 7 (in 2015) & 2012 & 2012 & $\begin{array}{l}\text { USA, Europe and } \\
\text { Asia }\end{array}$ & $\begin{array}{l}95 \%+\text { of revenues generated } \\
\text { in foreign markets (in 2015) }\end{array}$ \\
\hline Firm H2 & $\begin{array}{l}\text { Technology } \\
\text { venture-builder }\end{array}$ & ITC & 20 (in 2016) & 2014 & 2014 & $\begin{array}{l}\text { Mainly Europe and } \\
\text { USA }\end{array}$ & $\begin{array}{l}75 \%+\text { of revenues generated } \\
\text { in foreign markets (in 2016) }\end{array}$ \\
\hline Firm H3 & $\begin{array}{l}\text { Digital footprint } \\
\text { analysis }\end{array}$ & ITC & 6 (in 2016) & 2014 & 2015 & $\begin{array}{l}\text { Mainly Europe and } \\
\text { USA }\end{array}$ & $\begin{array}{l}50 \%+\text { of revenues generated } \\
\text { in foreign markets (in 2016) }\end{array}$ \\
\hline \multicolumn{8}{|c|}{ Lithuanian INVs } \\
\hline Firm L1 & $\begin{array}{l}\text { Open source } \\
\text { content system }\end{array}$ & ITC & 4 (in 2014) & 2013 & 2013 & $\begin{array}{l}\text { USA, Europe and } \\
\text { Asia }\end{array}$ & $\begin{array}{l}65 \% \text { of revenues generated in } \\
\text { foreign markets (in 2014) }\end{array}$ \\
\hline Firm L2 & $\begin{array}{l}\text { Visual feedback } \\
\text { solution }\end{array}$ & ITC & 6 (in 2014) & 2013 & 2013 & Europe and USA & $\begin{array}{l}99 \% \text { of revenues are } \\
\text { accumulated in foreign } \\
\text { markets (in 2014) }\end{array}$ \\
\hline Firm L3 & $\begin{array}{l}\text { Web-mobile- } \\
\text { type platform }\end{array}$ & ITC & 150 (in 2014) & 2008 & 2009 & $\begin{array}{l}\text { USA and Western } \\
\text { Europe }\end{array}$ & $\begin{array}{l}99,99 \% \text { of revenues are from } \\
\text { foreign markets (in 2014) }\end{array}$ \\
\hline \multicolumn{8}{|c|}{ Polish INVs } \\
\hline Firm P1 & $\begin{array}{l}\text { Promotion and } \\
\text { marketing } \\
\text { (integrated } \\
\text { marketing) }\end{array}$ & ITC & 20 (in 2016) & 2009 & 2011 & $\begin{array}{l}\text { Norway, Finland, } \\
\text { Germany, the } \\
\text { Czech Republic, } \\
\text { Slovakia, } \\
\text { Switzerland, } \\
\text { Austria, Italy, } \\
\text { France, the UK }\end{array}$ & $\begin{array}{l}\text { above } 25 \% \text { of revenues } \\
\text { generated in foreign markets } \\
\text { (in 2016) }\end{array}$ \\
\hline Firm P2 & $\begin{array}{l}\text { Integrated } \\
\text { digital } \\
\text { marketing }\end{array}$ & ITC & 5 (in 2016) & 2014 & 2016 & $\begin{array}{l}\text { the Czech } \\
\text { Republic, the } \\
\text { Netherlands, } \\
\text { Germany }\end{array}$ & $\begin{array}{l}\text { above } 25 \% \text { of revenues } \\
\text { generated in foreign markets } \\
\text { (in 2016) }\end{array}$ \\
\hline Firm P3 & $\begin{array}{l}\text { Creative } \\
\text { marketing }\end{array}$ & ITC & 1 (in 2016) & 2010 & 2011 & $\begin{array}{l}\text { Australia, } \\
\text { Bangladesh, the } \\
\text { UAE, Canada, } \\
\text { Kuwait, Slovenia, } \\
\text { USA, the UK, Italy }\end{array}$ & $\begin{array}{l}\text { above } 25 \% \text { of revenues } \\
\text { generated in foreign markets } \\
\text { (in } 2016 \text { ) }\end{array}$ \\
\hline
\end{tabular}

\section{Detailed Description of the Case Studies}

\section{Hungarian Cases}

Firm H1. Founded in 2012, the company started with a bunch of friends working as IT developers and freelancers or employees of major software development services companies with international clientele. They wanted to be their own bosses and took advantage of the booming global software development market. Their first major client was one of their former employers, a global provider of mobile-based IT solutions. The team worked and lived in Hungary, but served clients from all over the world. The business grew quickly, and after 3 years the founder-manager chose to live a quieter life and sold the company to their biggest global client, the world's leading video experience company. Interestingly, they still work relatively independently, but their operations are financed by the multinational owner.
Firm H2. This company, founded in 2014, is currently an entrepreneur-owned builder of technology-related ventures. They focus on market financed solutions but manage them with a venture capital approach. As coowners in the ventures they support, they share responsibility, risk and success by providing skills and experience to their clients. Originally, the founders used to work in venture capital firms and were thinking about starting up their own venture. However, they did not want to commit to a single enterprise so they set up the venture builder. As part of this concept they own and co-manage a portfolio of technology firms financed from cash flow generated in the market. Their target markets were the major global markets from the start; they did not set up the business for the local market.

Firm H3. The company was founded in 2014 with a service offering of providing information to clients about their target audience (B2B2C). Their solutions focus on the digital footprint of the target group: next to the purchase 
and on-site activity, social media activities, demographical and psychographic data, as well as their community's behaviour. As a consequence they can advise their clients on what their customers actually need in terms of online content or services. The original idea of the start-up was to leverage the business opportunities inherent in the extensive usage of Facebook by large populations. The founder already had other businesses before and had experience dealing with venture capital firms. The international client portfolio of the company was quickly developed through his existing international network in and outside Europe. They currently have venture capital financing both from Hungary and abroad.

\section{Lithuanian Cases}

Firm $\boldsymbol{L 1}$ focuses on the development of websites and systems of content management. In 2011 the business idea of the free marketplace was tested for 3 months in an accelerator in Great Britain. In 2013 the company was founded in Lithuania by the team of 3 young entrepreneurs and raised EUR 250.000 funding from Lithuanian VCs "Practica Capital". Firm L1 is offering a standardized product which is publicized in other countries.

Firm L2 product is offered on a global scale. The firm was founded in Startup Sauna accelerator in Finland by young founder in 2013. Founder had study abroad experience. Startup Sauna provided a convertible loan of EUR 10.000 for business development. In December 2013 the company was moved to Lithuania. In February, 2014, Firm L2 has attracted investments of EUR 300.000 from two VCs - Kima Ventures (France) and Practica Capital (Lithuania).

Firm L3 is the web-mobile-type platform. Firm was founded in 2008 by two friends. Internationalization to the first foreign market began in 2009, when the web platform was introduced in Germany. In 2011, a team of two entrepreneurs was joined by the third - serial entrepreneur, who had experience and invested to the company the amount of EUR 600.000, after that - company raised EUR 6.5 million from Accel Partners VCs (London Technology Fund VCs), and then from US VCs Insight Venture Partners - EUR 20 million.

\section{Polish Cases}

Firm P1 focuses on integrated marketing. The company was founded in Poland in 2009 by two friends who were bored with working for someone else. One of the founders, although of Polish origin, was born in Spain. The firm internationalised because the founders found work with a foreign client attractive and wanted to have a feeling that they were doing something bigger than in Poland. This is a rare example of the company in which employees are allowed to read Internet and check Facebook during a working day as it may give them new inspirations for work. During its first year of activity the firm operated within Academic Business Incubator.

Firm $P 2$ is an on-line marketing agency established in 2014. The founder was brought up in a family of entrepreneurs and wanted to do something that made pleasure on everyday basis and was a result of her long interest in marketing, sociology and psychology. Internationalisation was a natural effect of firm's growth.
Firm P3 was founded in 2010 originally doing graphic designs for social media and social media campaigns for customers from all over the world. It was international from the start because the founder preferred distant on-line contact with people than face-to-face contact with a client. This business was a continuation of earlier interest of the founder in Fine Arts. Over the time the initial business was abandoned and now the firm provides services relating to production, editing and post-production of $360^{\circ}$ videos for virtual reality and other pro-social, humanitarian and medical uses of the new technology.

\section{Cross - Case Analysis, Propositions and Findings}

\section{Previous Work Experience}

In the literature review section we showed how previous founders' work/industry experience is important to early internationalization of INVs.

The previous work experiences of Hungarian founders vary greatly. In case of Firm H3, the founder just finished business school, and soon after started his current company. Interestingly, he studied in California at an entrepreneurial programme and worked on a number of business projects and market testing as part of his studies. He also gained his first clients in the USA even before he formally started the venture coming back to Hungary.

The founders of Firm H2 had more experience before starting up the company. They were working for a venture capital firm investing into early stage companies. They have learned from their own experience that external funding is available when firms have momentum, and it is quite difficult to get financing when the cash flow generation of the firm falls back. Hence they had the idea that they want to work in a cash-flow business, i.e. in a company that generates enough revenues from the market so that it can sustain its continuous development. They also learned from the venture capital experience that single ventures can be very risky, therefore they wanted to have a portfolio of companies; hence the idea of a venture builder. Overall, they had significant business and entrepreneurship experience before starting up their current company. Regarding Firm H1, the founder had substantial experience as an employee in software development before he decided to start up a software development company of his own together with competent friends also involved in the industry. However, he did not have any entrepreneurial experience.

Lithuanian case analysis shows that entrepreneurs, with the previous experience learned to attentively listen to consumers' wishes, accumulated required ideas, skills and competencies for current activities. In this respect, one of the founders said: „Gained experience is helping to understand certain users better. From the other side, all practice, experience, in general, is helping in communication". Previous entrepreneurial experience amends the lack of organizational experience needed for internationalization. The majority of the Lithuanian INVs' founders worked very short periods of time. Founder of Firm L3 has worked only in a few workplaces until the establishment of the firm. Firm L1 founder was trying to reach his goal purposefully and all previous work experience was related to website development, programming. Firm L2 founder's experience was related to financial institutions, later he 
founded his own company. Moreover Firm L1 and Firm L2 founders worked in other start-ups and had established their own businesses.

On the basis of Polish case studies, all of the founders had some previous work experience but only few of them occupied managerial positions before. Similarly, three interview participants had previous business experience. Polish INVs founders' business activity was in some way related to their earlier experience or interests. Three of the founders had entrepreneurial role models among their close relations and one among his friends. One of these founders said "So I was born in a business-related environment and I was also educated and brought up in this way. That is in the context of money, settlements, invoices, negotiations and various strategic approaches to business. I discussed it with my dad at Sunday tea, dinner. I was 10-11 years old then." Thus we formulated the following proposition:

Proposition 1. The founders of the INVs from CEE transition economies had direct industry experience before starting up the new venture.

\section{Prior International Experience}

As it was mentioned before, founders of INVs international experience is important to successful internationalization.

All founders of the companies in the Hungarian sample had significant international experience before starting up their current venture. The founder of Firm H3 studied in the USA, in a multicultural environment and managed to get his first American clients while studying. The founders of Firm H2 were active in the venture capital business analysing and investing into other businesses with diverse international ownership background and exposure to global markets. The founder of Firm H1 was working as a software developer working for a global firm serving clients from all across the globe. The expectations he faced in his daily job were not reflecting domestic market conditions but very much the expectations of clients from the most competitive global markets.

The INVs founders from Lithuania had either studies or work experience from abroad. Entrepreneurs, who gained the most experience, internationalize firms' activities faster, as they are more self-confident, flexible, know right personalities to work with. One of founder declared: „Previous international experience has brought knowledge, skills and contacts". Results from Lithuania are mixed. Firm L2 founder left to Silicon Valley to the startup accelerator and sought to gain international experience. He works with Belarusian startup as well. Firm L2 founder also had study abroad experience. Firm L3 founders cooperated with partners from Germany from the beginning. Firm L1 founder gained international experience after establishment of INVs.

The results from the interviews with INVs founders from Poland showed that they had no prior international business experience abroad, however one of Firm P1 founders was born in Spain and the other made frequent business trips. Interviewees had only limited contact with foreign countries during their holiday trips. Only one of the founders had already had relations with foreigners living in Poland and maintained them later on. All of the Polish INVs founders could speak foreign languages before they set up their companies but their language levels varied. Almost all of them could speak English, however not all of them at the advanced level. One interviewee admitted the knowledge of Russian and one of German. Both founders of Firm P1 spoke two languages. Thus we formulated the following proposition:

Proposition 2. Most of the founders of the INVs from CEE transition economies had worked, lived or got education abroad in at least one foreign market before starting up the new venture.

Global vision, entrepreneurial orientation and personal features/ characteristics

Early internationalization is inherent from entrepreneurs ability to think globally from the very beginning of his/her business.

The mindset of the entrepreneurs in our Hungarian sample has been quite global even before starting up the companies. They all established their businesses for the major international markets with little attention paid to the domestic market. However, the role of early domestic clients was still important for Firms $\mathrm{H} 2$ and $\mathrm{H} 3$, as they generated cash flow and credentials vital for the firms' continued international expansion.

Regarding the characters of the founders' significant differences could be noted. The founders of Firms $\mathrm{H} 2$ and $\mathrm{H} 3$ were very determined to build a successful international business and do all they could to gain additional foreign clients both in the beginning and also at the consequent growth stages of the firms' development. The founder of $\mathrm{H} 2$ noted: "We did not start our business for the Hungarian market. We have issues with the current state of Hungarian business culture, and also the market is not lucrative enough. Software development is not a location specific business anyway." By contrast, the founder of Firm Hl enjoyed the major engagements coming from their first global clients, and was under less pressure to go out for new clients on a daily basis. The lucrative engagements made his senior colleagues unwilling to go the extra mile for business development, and the founder also got tired of doing the networking and sales activities on his own. This led to the eventual acquisition of the venture by their biggest client a few years after establishment.

Narratives from Lithuanian results show that international vision was clearly demonstrated by the already completed early internationalization. Founders of surveyed firms began to think about business expansion abroad even before the establishment of business. In most cases, motivation is related to the entrepreneur and his/her personality as achieving set goals, self-realization, internal ambitions are one of the strongest motivators occurred during the analysis.

The important role for internationalization of the firm's activities is played by personal character traits. Narrative shows that such features as patience, curiosity, determination, optimism, initiative, proactivity, social accessibility, leadership, self-confidence, innovativeness and faith emerged.

All three selected Lithuanian companies' founders tried to recognize the opportunities quickly and take a risk. Firm L2 founder has tried various options before found out his field of activity. The narratives revealed a direct link between opportunities and higher risk taking Most founders of Lithuanian selected INVs are tending to take a higher risk for 
higher profitability and improvement of performance. It was very well worded by one of them: "I am willing to take high risks for greater return. Innovative business is always associated with high risk". Some founder members, despite the risk taking, are seeking to justify and measure it, and not just only believe in blind success The founder of L1 commented: "Everything we are striving by hard work. Opportunities appear during work".

Due to the fact that interviewees from Poland expressed beforehand their unwillingness to speak about strategic issues they were not asked directly about the vision they had of their business at the beginning of their activities. However, their responses suggest that various forms of the vision of their company's future existed in all of the cases. It ought to be noted that only the founder of Firm P3 had clear intent of internationalisation from the start but in every case the vision took its proper form after a certain, although relatively short, period of time that passed since the firm had been established.

The INVs founders from Poland were asked to describe their attitude to risk, the way they identify business opportunities and their features of character. All of the interviewees responded that they took risks although some of them did not like it. One of the founders of Firm PI commented on his partners: "One is a visionary with fantasy and the other looks at numbers and results and says when to stop." In most of the cases this was defined as justified risk. Only two of the interview participants indicated they were not afraid of taking risks. Interestingly, the interviewee from Firm Pl who stated that he was not afraid of taking risks described the attitude towards risk of the co-founders of their company as conservative.

As for identifying business opportunities all of the interviewees are open to them and attempt to take advantage of them. However, some interview participants let the impulse guide them, while others rely on their intuition. Two interviewees indicated that they try to come up with their own ideas as well. This applies also to the co-founder of Firm P1 who is rather reserved with respect to the new opportunities and ideas. She performs her own analyses and, as the interviewee from Firm P1 described her attitude as, "tells us when to stop".

The features of character mentioned during the interviews include (although not in all of the cases): determination, perseverance, involvement, empathy, openness and creativity. It appears that the features common to all the interviewees are openness to others and networking skills. This applies also to the founder of Firm P3 who was initially afraid to get in touch with people and launched an online business activity to avoid face-to-face contacts. Nevertheless, he overcame his reluctance and does not experience such problems anymore. Thus we formulated the following proposition:

Proposition 3. Most of the founders of the INVs from CEE transition economies have global vision and entrepreneurial orientation towards international markets and new opportunities.

\section{Social Capital (Relational Capital)}

The Hungarian entrepreneurs involved in our sample emphasised the relevance of their existing relational capital when making the decision to establish their companies, as well as winning their early clients. For Firm H3, the active international networking activities, the founder called "hustling", is at the very heart of their business development efforts. The founder gained his first international relationships while studying in the USA and also when presenting the new start-up concept at start-up conferences and competitions. The venture capital investors in the firm also significantly contributed to the networking success of the firm. The founder emphasised the importance of networking in the firm's success: "It is a honey jar that attracts bees. What opportunity will you bring to others? Your network will be built as much as you can provide values to others." The founder of Firm H2 emphasised that his personal network of relationships allowed winning their first projects and also their continued expansion internationally was largely built around his direct contacts. However, they have got to a stage now that the scalability of the business can be limited by the size of his existing network; hence their current investment into inbound marketing to generate more relationships in the international markets. The founder of H2 noted: "I have existing relationships in the new markets we target. However, this is not scalable; it cannot generate a good deal flow. New relationships come from our developing track record, through our venture capital partners, and conferences... This is a process; the company is less and less dependent on the founders." Regarding Firm H1, the former employers of the founder provided the first major engagements, and they developed additional business relationships through recommendations from existing clients.

From the Lithuanian side, partnerships are not considered as relationships that are restricted to the status of customer seller. It is more like relations which are creating the basis for further development of a firm, supporting the idea, trying to help in every way, re-selling, and advertising. Narratives showed that partnerships aren't so much helping to expand activities abroad, as far as trying to understand the real needs of the target segment. Possession of informal and formal contacts, domestic as well international, is mentioned by interviewees as one of the most important factors for expansion into foreign markets. Moreover, the founder of Firm L2 leverages the cooperation with public institutions able to promote the creation of start-ups, accelerators and their mentors in Lithuania, Finland and USA. However selected Lithuanian INVs founders explore more their social and informal networks comparing to formal ones, and rely more heavily on domestic than international ties (,We aren't member of any associations officially. But we participate in "Infobalt" events, in the British Chamber of Commerce events in Lithuania“).

On the basis of Polish case studies INVs founders spoke about having established relations with clients and with other partners or institutions in their environment. What should be stressed at this point is that, despite the above, the resource deficits indicated by the interviewees included not well developed relations with clients. Innovativeness and integration capacity were mentioned by firms as well.

All Polish interviewees commented on their cooperation with partners (Firm P2). Firm P3 reported having cooperated with permanent partners, while Firm P1 additionally engaged in cooperation with partners chosen for specific 
projects. The interviewee from Firm P3 commented that his company selected its partners with a specific task in mind. Firm P1 has domestic (70 \%) and foreign (30 \%) partners; Firm P3 - about $10 \%$ of foreign partners. In case of Firm P2 it constantly cooperates with a few other firms but every time it signs a formal contact with them.

Two other studied enterprises reported having formalised their cooperation with partners (Firm P1 and Firm P3). In addition, the interviewee from Firm P3 mentioned having established good and long-lasting relations with their partners. However not all the studied Polish firms are active in informal cooperation but Firm P1 is very active and innovative. The interviewee from Firm P1 said: "We are trying to introduce a rotational model, which consists in the fact that after two years we can transfer the client to another, friendly agency that we can recommend. ... Then the client from time to time, eg in the perspective of 5 years, is served by 4 agencies who know each other and communicate their full knowledge, do not act on the basis of competition and fight for the client, but try to do their best for him. Each of them adds their own brick, for the creative process and for introducing some new solutions." Thus we formulated the proposition:

Proposition 4. Most of the founders of the INVs from CEE transition economies at the start-up stage of INVs create social links in order to early internationalize.

\section{Discussion and Conclusion}

This paper investigates whether the entrepreneur related factors influence early internationalization of INVs from CEE countries through nine cases cross country comparison of INVs from Hungary, Lithuania and Poland. In this sense, there was a significant contribution with regard to the role of founder's in the accelerated internationalization of CEE countries INVs. Moreover, it can help understand the entrepreneur related determinants in different business environments.

Regarding Proposition 1, our samples from the three CEE countries show some diversity, but the relevance of industry experience gained before starting up the venture seems to be valid across all cases. However, the extent of this preliminary experience varies greatly, and does not seem to be a uniquely powerful factor of success: some of the founders started up their business soon after graduation at business schools, although they did gain practical experience during their business studies. Others have already had previous ventures, successful or unsuccessful; hence they were more focused on the actual business idea than then the general experience of running a company of their own. There were also entrepreneurs in our sample who had significant industry experience as employees of multinational firms before they decided to try themselves as entrepreneurs. This relatively significant role of preliminary industry experience may add to our understanding of the findings from Lamotte and Colovic (2015) who highlighted, based on a sample of INVs from CEE and Central Asia, that early internationalization is negatively affected by a firm's knowledge intensity.

In terms of Proposition 2, there is a contrasting difference between the preliminary international experience of Polish founders compared to their counterparts in Hungary and
Lithuania. Interestingly, some of the successful Polish entrepreneurs had little or no previous international experience, and even their knowledge of a foreign language was not up to business standards. By contrast, all the entrepreneurs in our Hungarian and Lithuanian sample studied and/or worked abroad before starting up their own ventures, or at least worked for multinational firms serving international clients in the globalised ITC industry.

While the generalisability of our results is limited by the smaller sample size, and we have not tested propositions regarding the reasons for this difference between the Polish and the Hungarian-Lithuanian experience, we assume that the sheer size of the domestic market in Poland may enable some local entrepreneurs to start up their businesses focusing on Poland, and they may see internationalisation as a potential option for the expansion of their firms once local operations confirm the validity of the business idea they are pursuing. This option for building the business on the local market is less valid for Hungarian start-ups facing a domestic market of $1 / 4$ of that in Poland, and even less so in Lithuania. This result adds to our understanding to regional internationalisation patterns described by Mihailova et al. (2015) who, on a Russian sample i.e. reflecting a relatively large domestic market, found that entrepreneurs' international experience was not significantly related to early internationalisation success, which is in line with our Polish results.

A similar pattern of findings can be seen regarding Proposition 3. Entrepreneurs in the Hungarian and Lithuanian samples share a global mindset and entrepreneurial skill-set, while their Polish counterparts seem to have more gradually set their eyes on international markets, as their business in the relatively large domestic market got some momentum. Again, we have not tested our assumption that market size may be the reason behind the difference, but the preliminary anecdotal evidence looks compelling.

On the other hand, this result is somewhat surprising, in light of the shared historical experience of the population of all three countries. People share their belief that major Western markets normally offer better business opportunities and provide the basis of more mature, financially robust lifestyles not many entrepreneurs can expect in their home environment. This is confirmed by the sheer number of expatriates from these countries working in Western Europe. Unhappiness with the domestic environment not just business-wise but from many other aspects could be a key "domestic push" factor that drives the internationalisation of newly established firms in this region. Our findings from the Polish sample highlight the potential of intraregional differences along this line of thought.

Another regional aspect of our results highlights that becoming an entrepreneur is an attractive way of life for the founders of the firms in our sample. They saw this as an opportunity to get in touch with the most competitive global markets; hence they can leapfrog from the limitations of the domestic market and become part of the leading-edge international marketplace. On the other hand, they still face limitations in resources when starting up their ventures which they can manage based on the culture of effectuation "inherited" from the socialist times when private entrepreneurship was acquiesced to but not promoted by 
the political leadership. They have role models in their local environment regarding how to be clever finding ways to move forward despite being severely limited by access to capital, know-how and restrictive legal environment. Similar conclusions were reached by Nowinski and Rialp (2013) who proposed that resource limitations tend to drive INVs from CEE countries to efficiently use their resources and be very flexible in adapting to changing market conditions.

Proposition 4 focused on the founders' willingness and ability to create social links internationally in order to support their companies' success abroad. In our findings there are differences in terms of the breadth and depth of relationships founders found appropriate for their own business development efforts. Having seen the results regarding our previous propositions, it is no surprise that entrepreneurs in Hungary and Lithuania confirmed to pay much more attention to continuous and comprehensive networking in major foreign markets, in line with previous research in both Hungary (Czako \& Konczol, 2014) and Lithuania (Sekliuckiene, 2017) highlighting that initiatives to create sustainable international contacts can positively affect successful early-stage internationalisation. By contrast, again, Polish firms in our sample seem to be more selective in their efforts to building new relationships abroad. Nevertheless, the role of networks in developing the venture's international business has been important across all countries in our sample.

Interestingly, most of the social capital and personal relationships the founders of firms in our sample benefited from were directly related to the future target markets, mainly mature Western or global markets, and the role of domestic relationships mattered less than expected. This conclusion refines findings from Lamotte and Colovic (2015) who found in their research that networks in the home country and international networks are both supporting factors in early internationalisation success in this region. Similar conclusion was reached by Sekliuckiene (2017) on a Lithuanian sample who found that Lithuanian entrepreneurs put more emphasis on generation of informal and social connections rather than making efforts to develop a formal relationships in the foreign market.

Our Polish sample shows somewhat different patterns than our Hungarian and Lithuanian findings for the potential reasons explained above. The existing relationships of the founders seemed to help the ventures more in relation to understanding the demand conditions in future target markets than in terms of actual introduction to their first foreign clients.

Nevertheless, even if indirectly, the founders' existing contacts almost always helped the firms in their early internationalisation efforts abroad. Our current findings may be further refined in the subsequent stages of our research, and could be cross-checked with results from Musteen et al. (2014) who noted in their analysis of Czech manufacturing firms that while reliance on international networks can actually support internationalization, these relationships may have larger or less impact based on firms' emphasis on technological innovation and perceived environmental hostility.
Overall, we concluded that there may be regional characteristics related to the founders' ${ }^{\text {role in the }}$ internationalisation of INVs from Central-Eastern Europe. While full confirmation of our preliminary findings needs further empirical investigation, our indicative results highlight that the lure of better living standards and more supportive entrepreneurial culture attract local entrepreneurs to enter major, more developed markets at an early stage, while the level of this attraction appears to be moderated by a larger domestic market.

\section{Theoretical and Managerial Implications}

Our findings suggest that from many aspects, the internationalisation patterns of INVs from the CEE region share the key entrepreneurial level drivers identified for INVs in more mature markets (Matiusinaite \& Sekliuckiene, 2015). The notable differences may provide the basis of features specific to the region, including founders' willingness to be engaged in the most competitive global markets from the very start, and taking advantage of role models from the preliminary entrepreneurship approaches of the late socialist times (Nowinski \& Rialp, 2013). Interestingly, Polish firms in our sample show idiosyncratic development patterns, presumably related to the relatively large domestic market that offers early-stage growth opportunities for local INVs (Mihailova et al., 2015).

Founders and managers of current and future INVs from the CEE region may benefit from understanding our results in terms of the confirmed strong role of the personality of the founders, and their potential competitive advantages stemming from the historical entrepreneurial patterns related to developing ventures even in a limitedresources environment (effectuation strategies). This conclusion adds to our understanding of region-specific characteristics of potential INV internationalisation strategies as described by extant literature (Ciszewska \& Mlinaric et al. 2016; Nowinski \& Rialp, 2013).

\section{Limitations and Further Research}

Our study limitation is related to sample size, which is relatively small. Moreover, CEE countries are at different levels of market size and institutional transition, thus in these countries (Hungary, Lithuania and Poland) changes appear at different intensities. Further research could include a wider undertake due to representativeness of study results. All three groups of factors (entrepreneur related, firm related and contextual factors) leading to early internationalization should be included in cross - country comparison. Separation of factors determining early internationalization in different emerging markets contexts would allow to verify the dependence on the factor of transition market profile. Other studies could include comparison of INVs internationalization drivers from developed and transition countries. Furthermore, research using quantitative methods is necessary in the context of transition CEE economies, enabling INVs and international entrepreneurship theory development for transition markets. 


\section{Acknowledgements}

This research was partly supported by the Research, Development and Innovation Fund of Kaunas University of Technology (grant No. PP32/1810). Polish contribution was financed from SGH Warsaw School of Economics Faculty of Management and Finance Statutory Research (grant No. KZIF/S16/19/16).

\section{References}

Almeida Moraes, S. T., de Rocha, A., \& Ferreira da Silva, J. (2017). Network use in internationalization processes: a longitudinal study on the software industry. Review of International Business, 12(1), 76-90. https://doi.org/10.185 68/1980-4865.12162-75

Andersson, S., \& Evangelista F. (2006). The Entrepreneur in the Born Global Firm in Australia and Sweden. Journal of Small Business and Enterprise Development, 13(4), 642-659. https://doi.org/10.1108/14626000610705796

Amoros, J. E., Basco, R., \& Romank, G. (2014). Determinants of early internationalization of new firms: the case of Chile. International Entrepreneurship and Management Journal, 12(1), 1-25. https://doi.org/10.1007/s11365-0140343-2

Andersson, S., \& Evangelista, F. (2006). The Entrepreneur in the Born Global Firm in Australia and Sweden. Journal of Small Business and Enterprise Development, 13(4), 642-659. https://doi.org/10.1108/14626000610705796

Andersson, S., Danilovic, M., \& Huang, H. (2015). Success factors in Western and Chinese born global companies. Journal of Business, 7(1), 25-38. https://doi.org/10.4236/ib.2015.71004

Autio, E., Sapienza, H. J., \& Arenius, P. (2005). International Social Capital, Technology Sharing, and Foreign Market Learning in Internationalizing Entrepreneurial Firms. Advances in Entrepreneurship, Firm Emergence and Growth, 8, 9-42. https://doi.org/10.1016/S1074-7540(05)08002-5

Autio, E., George, G., \& Alexy, O. (2011). International entrepreneurship and capability development-Qualitative evidence and future research directions. Entrepreneurship Theory and Practice, 35(1), 1137.https://doi.org/10.1111/j.1540-6520.2010.00421.x

Baxter, P., \& Jack, S. (2008). Qualitative case study methodology: study design and implementation for novice researchers. The Qualitative Report, 13(4) Nova Southeastern University.

Choquette, E., Rask, M., Sala, D., \& Schroder, P. (2017). Born Globals - Is there fire behind the smoke? International Business Review, 26(3), 448-460. https://doi.org/10.1016/j.ibusrev.2016.10.005

Ciszewska-Mlinaric, M., Obloj, K., \& Wąsowska A. (2016). Effectuation and causation: Two decision-making logics of INVs at the early stage of growth and internationalisation. Journal of East European Management Studies, 21(4), 275-297.https://doi.org/10.5771/0949-6181-2016-3-275

Cressy, R. (1996). Are Business Startups Debt Rationed? The Economic Journal, 106(438), 1253-1270. https://doi.org/10.2307/2235519

Czako, E., \& Konczol, E. (2014). Critical Success Factors of Export Excellence and Policy Implications: The Case of Hungarian Small and Medium-Sized Enterprises. In: Gubik, A. S. \& Wach, K. (eds): International Entrepreneurship and Corporate Growth in Visegrad Countries: 69-84. Miskolc, Hungary: University of Miskolc.

Damon, W., \& Lerner, R. M. (2008). Entrepreneurship Across the Life Span: A Developmental Analysis and Review of Key Findings, A Kauffman Foundation White Paper, The Kauffman Foundation, Kansas City, MO.

Danik, L., \& Kowalik, I. (2013). The studies on born global companies - a review of research methods. Journal of Economics \& Management, 13, 10-16.

Danik, L., \& Kowalik I. (2015). Success factors and development barriers perceived by the Polish born global companies. Empirical study results. Journal of East European Management Studies, 20(3). https://doi.org/10.5771/0949-61812015-3-360

Dib, L. A., Rocha, A., \& Silva, J. F. (2010). The internationalization process of Brazilian software firms and the born global phenomenon: examining firm, network, and entrepreneur variables. Journal of International Entrepreneurship, 8(3), 233-253. https://doi.org/10.1007/s10843-010-0044-z

Dzikowski, P. (2018). A bibliometric analysis of born global firms. Journal of Business Research, 85, 281-294. https://doi.org/10.1016/j.jbusres.2017.12.054

Eisenhardt, K. M. (1989). Building Theories from Case Study Research. Academy of Management Review, 14(4), 53250. https://doi.org/10.5465/amr.1989.4308385

Etemad, H. (2017). Towards a conceptual multilayered framework of international entrepreneurship. Journal of International Entrepreneurship, 15(3), 229-238. https://doi.org/10.1007/s10843-017-0212-5 
Eurofound (2012). Born global: The potential of job creation in new international businesses, Publications Office of the European Union, Luxembourg.

European Bank for Reconstruction and Development, 1999, London.

Falay, Z., Salimaki, M., Ainamo, A., \& Gabrielsson, M. (2007). Design-intensive born globals: a multiple case study of marketing management. Journal of Marketing Management, 23(9/10), 877-899. https://doi.org/10.1362/ $026725707 \mathrm{X} 250377$

Felicio, A. J., Caldeirinha, V. R., \& Ribeiro - Navarrete, B. (2014). Corporate and individual global mind-set and internationalization of European SMEs. Journal of Business Research, 68(4), 797-802. https://doi.org/10.1016 /j.jbusres.2014.11.031

Ferencikova S. (2014). Born-globals vs. Born-graduals: An Exploratory Study of the Internationalization Patterns of Successful Slovak Firms. Saarbrucken: Lambert Academic Publishing.

Gabrielsson, P., \& Gabrielsson, M. (2013). A dynamic model of growth phases and survival in international business-tobusiness new ventures: the moderating effect of decision-making logic. Industrial Marketing Management, 42, 1357-1373. https://doi.org/10.1016/j.indmarman.2013.07.011

Garcia-Lillo, F., Claver-Cortes, E., Marco-Lajara, B., \& Ubeda-Garcia, M. (2017). Mapping the Intellectual Structure of Research on 'Born Global' Firms and INVs: A Citation/Cocitation Analysis. Management International Review, 57(4), 631-652. https://doi.org/10.1007/s11575-016-0308-5

Geldhof, J., Malin, M., Johnson, S. K., Porter, T., Bronk, K. C., Weiner, M., Agans, J. P., Mueller, M. K., Hunt, D., Colby, A., Lerner, R., \& Damon, W. (2014). Entrepreneurship in young adults: initial findings from the young entrepreneurs study. Journal of Applied Developmental Psychology, 35(5). $410-421$. https://doi.org/10.1016/j.appdev.2014.07.003

Gerschewski, S., Rose, E. L., \& Lindsay, V. J. (2015). Understanding the drivers of international performance for born global firms: An integrated perspective. Journal of World Business, 50(3), 558-575. https://doi.org/10.1 016/j.jwb.2014.09.001

Gimmon, E., \& Levie, J. (2010). Founder's human capital, external investment, and the survival of new high-technology ventures. Research Policy, 39(9), 1214-1226. https://doi.org/10.1016/j.respol.2010.05.017

Hair, J.F., Money, A.H., Samouel, P., \& Page, M. (2007). Research methods for business. West Sussex: John Wiley \& Son Ltd.

Harris, S., \& Wheeler, C. (2005). Entrepreneur's Relationships for Internationalization: Functions, Origins and Strategies. International Business Review, 14(2), 187-207. https://doi.org/10.1016/j.ibusrev.2004.04.008

Jarosinski, M. (2012). Sylwetka przedsiebiorcy - urodzonego globalisty (Entrepreneur's Profile in a Born Global). In R. Bartkowiak \& J. Ostaszewski (Eds.) Dorobek ekonomii, finansow i nauk o zarządzaniu oraz jego praktyczne wykorzystanie na przelomie XX i XXI wieku (Achievements of the Economy, Finance and Management Sciences as well as Their Practical Application on the Turn of 20th and 21st Century). Warsaw: Oficyna Wydawnicza SGH.

Jarosinski, M. (2013). Dylematy rozwoju polskich przedsiębiorstw. Dzialalność na rynku międzynarodowym alternatywa wczesnej internacjonalizacji (Growth Dilemmas of Polish Firms: The Alternative of Early Internationalisation). Report on statutory research. Warsaw: SGH Warsaw School of Economics.

Jarosinski, M., \& Mierzejewska W. (2017). Success Factors of International New Ventures from an Economy in Transition. Journal of East European Management Studies, 22(3), 287-309. https://doi.org/10.5771/0949-61812017-3-397

Kuivalainen, O., Sundqvist, S., \& Servais, P. (2007). Firms' degree of born-globalness, international entrepreneurial orientation and export performance. Journal of World Business, 42(3), 253-267. https://doi.org/10.101 6/j.jwb.2007.04.010

Laanti, R., Gabrielsson, M., \& Gabrielsson, P. (2007). The Globalization Strategies of Business-to-Business Born Global Firms in the Wireless Technology Industry. Industrial Marketing Management, 36(8), $1104-1117$. https://doi.org/10.1016/j.indmarman.2006.10.003

Kocak, A., \& Abimbola, T. (2009). The Effects of Entrepreneurial Marketing on Born Global Performance. International Marketing Review, 26(4/5), 439-452. https://doi.org/10.1108/02651330910971977

Kowalik, I., Danik, L., \& Sikora, T. (2017). Entrepreneurial orientation elements in the Polish international new ventures. Baltic Journal of Management, 12(2), 194-213. https://doi.org/10.1108/BJM-03-2016-0070

Knight, G. A., \& Cavusgil, S. T. (2004). Innovation, Organizational Capabilities and the Born-Global Firm. Journal of International Business Studies, 35(2), 124-141. https://doi.org/10.1057/palgrave.jibs.8400071

Knight, G. A., \& Liesch, P. W. (2016). Internationalization: From incremental to born global. Journal of World Business, 51(1), 93-102. https://doi.org/10.1016/j.jwb.2015.08.011 
Jurgita Sekliuckiene, Miroslaw Jarosinski, Miklos Kozma. Entrepreneurial Level Factors of Early Internationalization:...

Krueger, N. (1993). The impact of prior entrepreneurial exposure on perceptions of new venture feasibility and desirability, Entrepreneurship: Theory and Practice, 18(1), 5-21. https://doi.org/10.1177/104225879301800101

Kuivalainen, O., Puumalainen, P., Sintonen, S., \& Kylaheiko, K. (2010). Organizational capabilities and internationalization of the small and medium-sized information and communications technology firms. Journal of International Entrepreneurship, 8(2), 135-155. https://doi.org/10.1007/s10843-010-0057-7

Kyvik, O., Saris, W., Bonet, E., \& Felicio, J. A. (2013). The internationalization of small firms: The relationship between the globalmindset and firms' internationalization behaviour. Journal of International Entrepreneurship, 11, 172195. https://doi.org/10.1007/s10843-013-0105-1

Lamotte, O., \& Colovic, A. (2015). Early Internationalization of New Ventures From Emerging Countries: The Case of Transition Economies. Management, 18(1), 8-30. https://doi.org/10.3917/mana.181.0008

Lin, S., Mercier-Suissa, C., \& Salloum, C. (2016). The Chinese born globals of the Zhejiang Province: A study on the key factors for their rapid internationalization. Journal of International Entrpreneurship, 14(1), 75-95. https://doi.org/10.1007/s10843-016-0174-z

Martin, S. L., \& Javalgi, R. G. (2018). Epistemological Foundations of International Entrepreneurship. International Entrepreneurship and Management Journal, 14(3), 671-680. https://doi.org/10.1007/s11365-018-0517-4

Mathews, J., \& Zander, I. (2007). The international entrepreneurial dynamics of accelerated internationalisation", Journal of International Business Studies, 38(3), 387-403. https://doi.org/10.1057/palgrave.jibs.8400271

Matiusinaite, A., \& Sekliuckiene, J. (2015). Factors determining early internationalization of entrepreneurial SMEs: Theoretical approach. International Journal of Business and Economic Sciences Applied Research; 8(3), 21-32.

McDougall, P. P., \& Oviatt, B. M. (2000) International entrepreneurship: the intersection of two research paths. Academy of Management Journal 43(5), 902-906. https://doi.org/10.2307/1556418

Madsen, T. K. (2013). Early and rapidly internationalization ventures: similarities and differences between classifications based on the original international new venture and born global literatures. Journal of International Entreprenuership, 11, 65-79. https://doi.org/10.1007/s10843-012-0099-0

Masuo, D., Fong, G., Yanagida, J., \& Cabal, C. (2001). Factors associated with business and family success: a comparison of single man-ager and dual manager family business households. Journal of Family and Economic Issues, 22(1), 55-73. https://doi.org/10.1023/A:1009492604067

Mihailova, I., Shirokova, G., \& Laine, I. (2015). New venture internationalization from an emergent market: unexpected findings from Russia", Journal of East-West Business, 21(4), 257-291. https://doi.org/10.1080/10669868. 2015.1067276

Moen, O., \& Servais, P. (2002). Born Global or Gradual Global? Examining the Export Behavior of SMEs. Journal of International Marketing, 10(3), 49-72. https://doi.org/10.1509/jimk.10.3.49.19540

Musteen, M., Datta, D. K., \& Francis, J. (2014). Early internationalization by firms in transition economies into developed markets: the role of international networks. Global Strategy Journal, 4, $221-237$. https://doi.org/10.1002/gsj.1077

Naldi, N., \& Achtenhagen, L., \& Davidsson, P. (2015). International Corporate Entrepreneurship among SMEs: A Test of Stevenson's Notion of Entrepreneurial Management. Journal of Small Business Management, 53(3), 780-800. https://doi.org/10.1111/jsbm.12087

Ngo, V. D., \& Janssen, F., \& Falize, M. (2016). An incentive-based model of international entrepreneurship in emerging and transition economies. Journal of International Entrepreneurship, 14(1), 52-74. https://doi.org/10.1007/s10843016-0165-0

Nowinski, W., \& Rialp, A. (2013). Drivers and strategies of international new ventures from a Central European transition economy. Journal for East European Management Studies, 18(2), 191-231. https://doi.org/10.5771/09496181-2013-2-191

Ovaska, T., \& Sobel, R. (2005). Entrepreneurship in postsocialist economies. Journal of Private Enterprise 21(1), 8-28.

Oviatt, B. M., \& McDougall, P. P. (2005). Defining International entrepreneurship and modelling the speed of internationalization. Entrepreneurship Theory and Practice, 29(5), 537-553. https://doi.org/10.1111/j.15406520.2005.00097.x

Poulis, K., Poulis, E., \& Plakoyiannaki, E. (2013). The role of context in case of study selection: An international business perspective. International Business Review, 22(1), 304-314. https://doi.org/10.1016/j.ibusrev.2012.04.003

Rasmussen, E. S., \& Madsen, T. K. (2002). The Born Global Concept. Proceedings of the 28th Annual Conference of European International Business Academy (EIBA), 8-10 December, Athens, Greece. 
Rialp-Criado, A., Rialp-Criado, J., \& Knight, G. A. (2005). The phenomenon of early internationalizingfirms: what do we know after a decade (1993-2003) of scientific inquiry? International Business Review, 14(2), 147-166. https://doi.org/10.1016/j.ibusrev.2004.04.006

Rialp-Criado, A., Rialp-Criado, J., \& Knight, G. A. (2002). The Phenomenon of International New Ventures, Global Start-Ups, and Born-Globals: What Do We Know after a Decade (1993-2002) of Exhaustive Scientific Inquiry?. Proceedings of the 28th Annual Conference of European International Business Academy (EIBA), 8-10 December, Athens, Greece.

Rialp, A., Rialp J., \& Knight G. A. (2015). International entrepreneurship: a review and future directions. In S.A. Fernhaber \& S. Prashantham (Eds.), Routledge Companion on International Entrepreneurship, Routledge, New York, NY, 7-28.

Reid, S. (1981). The Decision Maker and Export Entry and Expansion. Journal of International Business Studies, 12(2), 101-112. https://doi.org/10.1057/palgrave.jibs.8490581

Roper, S. (1999). Modeling Small Business Growth and Profitability. Small Business Economics, 13(3), $235-252$. https://doi.org/10.1023/A:1008104624560

Santos, J. C., \& Barandas, H. K. (2015). Different conceptual approaches to the internationalization of the firms: a bibliometric review. Revista Ibero-Americana de Estrategia - RIAE, 14(4), 93-118. https://doi.org/10.55 85/riae.v14i4.2263

Sass, M. (2012). Internationalisation of innovative SMEs in the Hungarian medical precision instruments industry. PostCommunist Economies, 24(3), 365-382. https://doi.org/10.1080/14631377.2012.705470

Sekliuckiene, J. (2017). Factors leading to early internationalization in emerging Central and Eastern European economies: Empirical evidence from new ventures in Lithuania. European Business Review, 29(2), $219-242$. https://doi.org/10.1108/EBR-12-2015-0158

Sekliuckiene, J., Pisoni, A., Onetti, A., Cannone, G., \& Matiusinaite, A. (2017). Early internationalizing firms: the age effect on entrepreneurial behavior. World Review of Entrepreneurship, Management and Sustainable Development, 13(5/6), 707-733. https://doi.org/10.1504/WREMSD.2017.086344

Servantie, V., Cabrol, M., Guieu, G., \& Boissin, J. P. (2016). Is international entrepreneurship a field? A bibliometric analysis of the literature (1989-2015). Journal of International Entrepreneurship, 14(2), 168-212.

Stucki, T. (2016). How the founders' general and specific human capital drives export activities of start-ups. Research Policy, 45(5), 1014-1030. https://doi.org/10.1016/j.respol.2016.02.010

Vissak, T. (2006). Internationalisation of Estonian Listed Companies - Theories and Reality. In T. Mets \& J. Andrijevskaja \& U. Venesaar \& E. Kolbre (Eds.), Entrepreneurship in Estonia: policies, practices, education and research. Tartu: University of Tartu, edition 1, 28(28).

Yin, R. K. (2009). Case Study Research - Design and Methods, Sage Publications, Thousand Oaks, CA.

The article has been reviewed.

Received in July 2018; accepted in April 2019. 